Farming for Pleasure and Profit. Eighth SectionMarket Garden Husbandry for Farmers and General Cultivators. By William H. Ablett. (London : Chapman and Hall, Limited, 1881.)

THAT there is a certain amount of pleasure in farming culture as there is in every other occupation in life no one will deny, but whether the pleasure goes hand in hand with profit is another question. In these days of agricultural depression anything that can conduce to either pleasure or profit in farming would, we doubt not, be hailed by thousands; for farmers, however, to take up with market gardening in all its details as laid down by Mr. Ablett, would be to revolutionise the practice of farming as generally accepted, and to constitute themselves into market gardeners pure and simple, this the author seems to have considered impracticable, except in the neighbourhood of London or large towns where in the markets the produce can be quickly disposed of. To adopt a legal phrase we may say we do not think the author has made out a case for the more general adaptation of farm lands for market garden produce, because while fully believing that many of the more important vegetables might be cultivated on a much more extended scale, we do not see that the crops would be more profitable to the grower than those with which he is more accustomed, and which, instead of requiring an immediate sale, can be stored and disposed of at any time. But while many vegetables, more particularly root crops, as potatoes, carrots, parsnips, turnips, \&c., may with profit be grown by farmers, we very much doubt whether mushrooms would be generally taken up or prove advantageous, and still less so the morell and truffle, all of which are included in Chap. $X$, the two latter of which the author says are not objects of cultivation in this country, a remark that is quite true, and therefore it does not form the slightest excuse for admitting even a notice of them into the book. Still less can any excuse be found for the occupation of three-quarters of a page by the Fly Agaric (Agaricus muscarizus), a well-known poisonous species.

The final chapter of the book concludes with some remarks on flower growing, a branch of cultivation that would, we sbould think, seldom or never be united with that of farming proper. The brok is well printed, and is freer from typographical errors than is usually the case ; nevertheless there are errors in spelling that ought not to have occurred, such, for instance, as Solanum tzberosam for S. tuberosum, Lepidum for Lepidium, and Cochlearia armorica for Cochlearia armoracia. Notwithstanding that many other works exist which give full cultural details for growing market garden produce, we have no doubt that this latest production will be found of use to some growers.

\section{The Land of the Morning; an Account of Jatan and its}

Pcople. By William Gray Dixon, M.A. (Edinburgh : James (xeminell, I882.)

GENERAL works in Japan have increased so rapidly in recent years that the claims of every new writer on the subject may well be examined with attention. Those of Mr. Dixon are that he resided four years in Tokiô as Professor in the Engincering College there, that he travelled over nearly four thousand miles of the country, including many remote and mountainous districts, and that he was thrown into contact with representatives of all classes of Japanese society from Cabinet Ministers to peasants. To these may be added the further circumstance that really accurate and valuable books, such as those of Sir Edward Reed and Miss Bird, are somewhat expensive, while Mr. Dixon desired to furnish a moderate-sized volume at a moderate price. In this we think he has succeeded. "The Land of the Morning" is a handsome volume of nearly 700 pages, with numerous illustrations. When we examine the contents of the work, we find that they are in every way worthy of their handsome exterior. After a brief and apparently accurate sketch of Japanese history, and especially of the troubles whfch led to the revolution of $1868, \mathrm{Mr}$, Dixon describes new Japan, its institutions, and people. This he does with a sympathy which is all the more praiseworthy that it is the result of four years' close observation, and not the newly-developed ardour of a casual visitor. We turn with especial interest to $\mathrm{Mr}$. Dixon's account of Japanese students. Many young men from Japan have shown themselves matches for brilliant European students, notwithstanding the initial obstacle which they have to overcome in acquiring the language ; these, however, are clearly exceptions, and we therefore look to Mr. Dixon's experience for an account of the average Japanese student. He has devote 1 a whole chapter to the subject, and the picture is in some respects not a pleasant one.

Devotion to study, which frequently leads to overwork and permanent ill-health; attention and respect for the teacher ; good-humour ; an extraordinary development of memory; some originality, a high sense of honour and much gratitude, are all found in the average student ; but with these we find a self-conceit which is ridiculous, a mind clear rather than deep, and a " narrow intellectualis $n$ " which blinds him to the necessity for moral as well as intellectual development. If there is a rapid development there is also a rapid decay. The picture, we believe, is a true, albeit somewhat melancholy one.

The popular idea that Japanese isolation, which was first rudely broken by the American Commodore Perry in 1853 , was the result of hostility and prejudice towards foreigners, will receive a shock from Mr. Dixon's chapter on the subject. "The real cause," he says, "of Japan's exclusiveness was a fear that free intercourse with the outside world might lead her into subjection to some foreign power." Mr. Dixon is indignant that "an American gentleman of considerable fame in biology and cognate subjects"-. Prof. Morse, of Salem, we believe-cinstead of keeping within his own province," preached "atheistic evolution" in a temple at Asakusa in Tôkiô ; in other words, lectured on evolution and the Darwinian theory, and founded among his students a biological society which is still active and vigorous. 'The really good work which Prof. Morse did for education and science in Japan cannot be dismissed by a few abusive epithets, and we cannot help thinking that $\mathrm{Mr}$. Dixon would have acted more discreetly, and more in accordance with the general tone of the work, had he omitted references such as these. This, however, is but a minor blot in a work of such general excellence.

\section{A Study of the History and Meaning of the Expression} "Original Gravity." By J. A. Nettleton, of the Inland Revenue Laboratory, Somerset House. (London: A. Lampray, 188I).

T'HIs little treatise, the substance of which appeared in the Brewers' Guardian, has been compiled mainly for the information of brewers and distillers, and for the use of the officers in the Inland Revenue Department, in order to permit of the original gravity of a sample of wort of beer or of distillers' wash to be determined after fermenta. tion with a view of fixing the amount of drawback, in conformity with the Act ro Vict. cap. 5, I847, and the Inland Revenue Act, 1880 . There are four different methods in more or less common use for determining "original gravity" These are very fully described and the incidental errors carefully noted; preference is very properly given to the distillation process of Dobson and Phillips, with the modifications in the tables rendered necessary by the investigations of Graham, Hofmann, and Redwood, made at the instance of the Board of Inland Revenue. We can recommend the work as a thoroughly trustworthy guide to the brewer and distiller in a matter of great practical importance to their trades. 